\title{
Biomimetic $\mathrm{CO}_{2}$ Sequestration: 1. Immobilization of Carbonic Anhydrase within Polyurethane Foam
}

\author{
Ekrem Ozdemir* \\ Department of Chemical Engineering, Izmir Institute of Technology, Gulbahce Campus, Urla 35437, Izmir, Turkey
}

Received June 4, 2009. Revised Manuscript Received August 7, 2009

\begin{abstract}
Bovine carbonic anhydrase (CA) was immobilized within polyurethane (PU) foam for biomimetic $\mathrm{CO}_{2}$ sequestration. The catalytic activities for the free and immobilized CA were estimated using paranitrophenyl acetate ( $p$-NPA) as the substrate. Because the $p$-NPA has limited solubility in the aqueous phase, the activities were estimated in Tris buffer containing 10\% acetonitrile. A Lineweaver-Burk relationship was employed to estimate the Michaelis-Menten kinetic parameters for the free and immobilized CA. The $k_{\text {cat }}, K_{\mathrm{m}}$, and $k_{\text {cat }} / K_{\mathrm{m}}$ values for the free CA were found to be $2.02 \mathrm{~s}^{-1}, 12.2 \mathrm{mM}$, and $166.4 \mathrm{M}^{-1} \mathrm{~s}^{-1}$, respectively. The $K_{\mathrm{m}}$ value for the immobilized CA was estimated to be $9.6 \mathrm{mM}$ at the same conditions. The immobilized CA was stable and did not lose any activity over seven consecutive washings and activity tests. While the free CA lost its activity in 45 days stored at $4{ }^{\circ} \mathrm{C}$ in refrigerator, the immobilized CA maintained $100 \%$ of its activity over a 45 day period stored in Tris buffer at ambient conditions. It was concluded that the immobilized CA as a very stable biocatalyst could be employed in biomimetic $\mathrm{CO}_{2}$ sequestration.
\end{abstract}

\section{Introduction}

The atmospheric concentration of carbon dioxide $\left(\mathrm{CO}_{2}\right)$ has been increasing because of anthropogenic activities. ${ }^{1}$ To stabilize $\mathrm{CO}_{2}$ in the atmosphere, a number of $\mathrm{CO}_{2}$ sequestration methods have been proposed. ${ }^{2}$ In these sequestration options, $\mathrm{CO}_{2}$ has to be pure, for which $\mathrm{CO}_{2}$ has to be captured from the flue gases, compressed to the desired pressures, transported to a sequestration site, and finally, injected within the sequestration area for long-term storage. ${ }^{3}$ All of these processes increase the sequestration cost. ${ }^{4,5}$ The sequestration cost could be reduced if $\mathrm{CO}_{2}$ is captured and sequestered directly at the production sites. The production of valuable products from $\mathrm{CO}_{2}$, such as nanosized $\mathrm{CaCO}_{3}$, which is extensively used as fillers or pigment in paper, paints, and plastics industries, could make the sequestration process economically feasible. ${ }^{6,7}$ In this case, the $\mathrm{CO}_{2}$ should undergo a number of transformations, such as the dissolution in an aqueous phase (eq 1), hydration by water (eq 2), ionization (eq 3), carbonate formation (eq 4), and finally, the precipitation by the available $\mathrm{Ca}^{2+}$ ions

*To whom correspondence should be addressed. Telephone: +90(232)750-6685. Fax: +90(232)750-6645. E-mail: ekremozdemir@, iyte.edu.tr.

(1) Huessemann, M. H. Mitigation and Adoptation Strategies for Global Change 2006, 11, 539-577.

(2) Reichle, D.; Houghton, J.; Kane, B.; Ekmann, J. Carbon sequestration: Research and development. United States Department of Energy (DOE) Report, Pittsburgh, PA, 1999.

(3) Gentzis, T. Int. J. Coal Geol. 2000, 43, 287-305.

(4) Abadie, L. M.; Chamorro, J. M. Energy Econ. 2008, 30, 2992 3015

(5) McCoy, S. T.; Rubin, E. S. Int. J. Greenhouse Gas Control 2008, 219-229.

(6) Wang, L.; Sondi, I.; Matijevic, E. J. Colloid Interface Sci. 1999, $218,545-553$.

(7) Wu, W.; He, T.; Chen, J.-f.; Zhang, W.; Chen, Y. Mater. Lett. 2006, 60, 2410-2415.

(8) Mirjafari, P.; Asghari, K.; Mahinpey, N. Ind. Eng. Chem. Res. 2007, 46 (3), 921-926. (eq 4). ${ }^{8}$ Among these, the hydration of $\mathrm{CO}_{2}$ (eq 2) is the slowest step. ${ }^{9}$

$$
\begin{gathered}
\mathrm{CO}_{2}(\mathrm{~g}) \rightleftharpoons \mathrm{CO}_{2}(\mathrm{aq}) \\
\mathrm{CO}_{2}(\mathrm{aq})+\mathrm{H}_{2} \mathrm{O} \rightleftharpoons \mathrm{H}_{2} \mathrm{CO}_{3} \\
\mathrm{H}_{2} \mathrm{CO}_{3} \rightleftharpoons \mathrm{HCO}_{3}{ }^{-}+\mathrm{H}^{+} \\
\mathrm{HCO}_{3}{ }^{-} \rightleftharpoons \mathrm{CO}_{3}{ }^{2-}+\mathrm{H}^{+} \\
\mathrm{Ca}^{2+}+\mathrm{CO}_{3}{ }^{2-} \rightleftharpoons \mathrm{CaCO}_{3}
\end{gathered}
$$

When the $\mathrm{pH}$ is higher than 10 , eq 6 dominates for the carbonate formation. ${ }^{10}$ When the $\mathrm{pH}$ is less than 8 , eq 6 is negligible.

$$
\mathrm{CO}_{2}(\mathrm{aq})+\mathrm{OH}^{-} \rightleftharpoons \mathrm{CO}_{3}{ }^{2-}+\mathrm{H}^{+}
$$

Attempts have been made to enhance the hydration of $\mathrm{CO}_{2}$ in the presence of a biocatalyst, carbonic anhydrase (CA) ${ }^{8,11,12}$ The CA (EC 4.2.1.1) is a zinc-containing metalloenzyme that mainly catalyzes the reversible hydration of carbon dioxide $\left(\mathrm{CO}_{2}\right){ }^{13}$ The CAs can also catalyze the dehydration of various aldehydes and the hydrolysis of esters, which are very useful for activity assays. ${ }^{14-16}$ There are at least

(9) Dreybrodt, W.; Lauckner, J.; Zaihua, L.; Svensson, U.; Buhmann, D. Geochim. Cosmochim. Acta 1996, 60 (18), 3375-3381.

(10) Bond, G. M.; Stringer, J.; Brandvold, D. K.; Simsek, F. A.; Medina, M. G.; Egeland, G. Energy Fuels 2001, 15 (2), 309-316.

(11) Bond, G. M.; Stringer, J.; Brandvold, D. K.; Medina, M. G.; Simsek, F. A.; Egeland, G. Abstr. Pap. Am. Chem. Soc. 2000, 220, U395U395.

(12) Liu, N.; Bond, G. M.; Abel, A.; McPherson, B. J.; Stringer, J. Fuel Process. Technol. 2005, 86 (14-15), 1615-1625.

(13) Tripp, B. C.; Smith, K.; Ferry, J. G. J. Biol. Chem. 2001, 276, 48615-48618.

(14) Whitney, P. L. Eur. J. Biochem. 1970, 16, 126-135.

(15) Pocker, Y.; Stone, J. T. Biochemistry 1968, 7 (9), 3021-3031.

(16) Innocenti, A.; Scozzafava, A.; Parkkila, S.; Puccetti, L.; Simone, G. D.; Supuran, C. T. Bioorg. Med. Chem. Lett. 2008, 18, 2267-2271. 
five classes of CA, structurally characterized as $\alpha, \beta, \gamma, \delta$, and $\varepsilon$ classes. ${ }^{17-19}$ These CAs are found in most eukaryotic and many microbial organisms. $\alpha$-CA belongs to mammals and divided into four subgroups: cytosolic, mitochondrial, secreted, and membrane bound. ${ }^{20}$ There are 16 different isozymes in mammals, and at least 10 of them are human isozymes. ${ }^{21}$ $\beta$-CAs belong to prokaryotic and plant chloroplast. ${ }^{22,23}$ $\gamma$-CAs are from methane-producing bacteria that grow in hot springs. $^{20}$ Recently, $\delta$ - and $\varepsilon$-CA have also been identified. ${ }^{24}$ The catalytic active site of CAs consists of a $\mathrm{Zn}^{2+}$ ion, which forms coordination bonds with the nitrogen atoms of three histidine residues. ${ }^{19}$ There are 18 lysine groups in the amino acid sequence of CA, and most of them are at the surface of the enzyme. $^{25}$ The lysines containing amine groups provide the enzyme-efficient immobilization. The mechanism of the hydration of $\mathrm{CO}_{2}$ by the CA enzyme is initiated by a nucleophilic attack on the carbon atom of $\mathrm{CO}_{2}$ by the zinc-bound $\mathrm{OH}$ group to produce bicarbonate, which is then displaced from zinc by a water molecule. ${ }^{8}$ The diverse classes of $\mathrm{CA}$ have different activities for $\mathrm{CO}_{2}$ and other substrates. ${ }^{15-17,25-28}$

Carbon dioxide was shown to be used in biomimetic processes. Bond et al. ${ }^{10}$ developed an integrated system for biomimetic $\mathrm{CO}_{2}$ sequestration, which employed the enzyme $\mathrm{CA}$ to accelerate the rate of $\mathrm{CO}_{2}$ hydration for the subsequent fixation into stable mineral carbonates. Mirjafari et al. ${ }^{8}$ investigated the application of the CA to enhance the hydration of $\mathrm{CO}_{2}$ in the solution. Liu et al. ${ }^{12}$ studied the precipitation of $\mathrm{CaCO}_{3}$ from produced waters in the presence of the CA enzyme. However, there are some disadvantages using the free enzyme in solution, such that the stability of the enzyme is low, its repeatable usage is limited, and recovery from the reaction environment generally will not be possible. These disadvantages can be eliminated by immobilizing the enzyme. There are some enzyme immobilization techniques, such as entrapment in matrices, adsorption on the solid surfaces, covalent bonding, and cross-linking within polymeric networks. ${ }^{29} \mathrm{CA}$ has been immobilized on some solid and polymeric supports. Drevon et al. ${ }^{25}$ immobilized CA in coatings by covalent attachment. Liu et al. ${ }^{12}$ immobilized CA on chitosan-alganite beads by encapsulation. Jovica and Kostic ${ }^{30}$ immobilized CA within silica monoliths by the sol-gel method.

(17) Supuran, C. T.; Scozzafava, A.; Conway, J. Carbonic Anhydrase. Its Inhibitors and Activators; CRC Press: New York, 2004; Vol. 1.

(18) So, A. K.; Espie, G. S.; Williams, E. B.; Shively, J. M.; Heinhorst, S.; Cannon, G. C. J. Bacteriol. 2004, 186, 623-630.

(19) Cox, E. H.; McLendon, G. L.; Morel, F. M.; Lane, T. W.; Prince,

R. C.; Pickering, I. J.; George, G. N. Biochemistry 2000, 39, 1212812130 .

(20) Esbaugh, A. J.; Tufts, B. L. Respir. Physiol. Neurobiol. 2006, 154, $185-198$.

(21) Hewett-Emmett, D.; Tashian, R. E. Mol. Phylogenet. Evol. 1996, $5(1), 50-77$.

(22) Temperini, C.; Scozzafava, A.; Vullo, D.; Supuran, C. T. J. Med. Chem. 2006, 49, 3019-3027.

(23) Smith, K. S.; Ferry, J. G. FEMS Microbiol. Rev. 2000, 24, 335366.

(24) Host, G. Engineering carbonic anhydrase for highly selective ester hydrolysis. Ph.D. Dissertation, Linkoping University, Sweden, Linkoping, 2007.

(25) Drevon, G. F.; Unbarke, C.; Russell, A. J. Biomacromolecules 2003, 4, 675-682.

(26) Thorslund, A.; Lindskog, S.; Europen, J. Biochemistry 1967, 117123.

(27) Duda, D. M.; Tu, C.; Fisher, S. Z.; An, H.; Yoshioka, C.; Govindasamy, L.; Laipis, J. L.; McKenna, M. A.; Silverman, D. N.; McKenna, R. Biochemistry 2005, 10046-10053.

(28) Pocker, Y.; Stone, J. T. Biochemistry 1967, 6 (3), 668-678.

(29) Shuler, M. L.; Kargi, F. Bioprocess Engineering; Prentice Hall: New York, 2002.

(30) Jovica, D. B.; Kostic, N. M. Chem. Mater. 1999, 11, 3671-3679.
Cheng et al. ${ }^{31}$ immobilized CA within the poly(acrylic acidco-acryamide) hydrogel by entrapment. Hosseinkhani and Gorgani $^{32}$ immobilized CA on a hydrophobic adsorbent of Sepharose 4B by adsorption. The immobilization in coatings as well as entrapment within sol-gels and alginate beads would yield the diffusion limitation, whereas the adsorption on the solid adsorbents would yield a detachment of the enzyme during the process. Therefore, more efficient immobilization methods are needed.

Polyurethanes (PUs) have been shown to be widely used supports for immobilization of enzymes and cells. ${ }^{33}$ Wood et al. ${ }^{34}$ patented a method of irreversibly immobilizing enzymes within PU in 1982. Today, their method is still used in enzyme and cell immobilization and includes mixing of a HYPOL prepolymer with the aqueous enzyme or cell solution. ${ }^{33-37}$ Figure 1a shows a chemical structure of the HYPOL as the prepolymer of poly(ethylene glycol) capped with isocyanate-terminated end groups. ${ }^{38}$ Figure $1 \mathrm{~b}$ shows a possible mechanism of immobilization of enzymes within the PU foam and the polymerization of the prepolymer in the presence of water, which are deduced from the isocyanate chemistry. ${ }^{39}$ The polymerization is initiated by a nucleophilic attack by an $\mathrm{OH}^{-}$at the carbonyl group following a protonation and deprotonation and a release of $\mathrm{CO}_{2}$ from an unstable intermediate, thus converting one isocyanate group into an amine group $\left(\mathrm{NH}_{2}\right)$. The produced $-\mathrm{NH}_{2}$ groups react immediately with a neighboring isocyanate group, resulting in a cross-linking between two prepolymer chains. This process continues until all of the isocyanate groups were consumed. As a result, the generated $\mathrm{CO}_{2}$ causes a porous and sponge-like polymeric matrix of the PU foam. Because the amine and/or hydroxyl groups are readily available on the surface of the enzyme, the enzyme is preferentially crosslinked by the isocyanates of the prepolymer. Consequently, a covalently immobilized enzyme containing biocatalytic material can be obtained in a cross-linked form. The advantages of this assay are that the process is faster and higher activity retention could be obtained. ${ }^{33-36,40}$

Although PUs are widely used supports for immobilization of enzymes and cells, ${ }^{33,35-37,40}$ to the best of the author's knowledge, the CA has not been immobilized within PU foam. In the present work, the CA was immobilized within $\mathrm{PU}$ foam covalently by cross-linking for the biomimetic $\mathrm{CO}_{2}$ sequestration purposes.

\section{Materials and Methods}

2.1. Materials. CA from bovine erythrocytes (MW, $29000 ; 89 \%$ pure in protein as dialyzed and lyophilized powder), para-nitrophenyl

(31) Cheng, L.-H.; Zhang, L.; Chen, H.-L.; Gao, C.-J. J. Membr. Sci. 2008, 324, 33-43.

(32) Hosseinkhani, S.; Gorgani, M. N. Enzyme and Microb. Technol. 2003, 33, 179-184

(33) Romaškevič, T.; Budriene, S.; Pielichowski, K.; Pielichowski, J. Chemija 2006, 17 (4), 74-89.

(34) Wood, L. L.; Hardegen, F. J.; Hahn, P. A. Preparation and use of enzymes bound to polyurethane. U.S. Patent 4,342,834, 1982.

(35) LeJeune, K. E.; Mesiano, A. J.; Bower, S. B.; Grimsley, J. K.; Wild, J. R.; Russell, A. J. Biotechnol. Bioeng. 1997, 54 (2), 105-114.

(36) LeJeune, K. E.; Russell, A. J. Biotechnol. Bioeng. 1996, 51, 450457.

(37) Wood, L. L. J. Cell. Plast. 1976, Sept/Oct, 285-288.

(38) HYPOL Laboratory Procedures and Foam Formulations. W.R. Grace and Co., New York; pp 1-12.

(39) Morrison, R. T.; Boyd, R. N. Organic Chemistry, 4th ed.; Allyn and Bacon, Inc.: Boston, MA, 1959; p 1370.

(40) Bakker, M.; Velde, F.; Rantwijk, F.; Sheldon, R. A. Biotechnol. Bioeng. 2000, 70 (3), 342-348. 
(a)

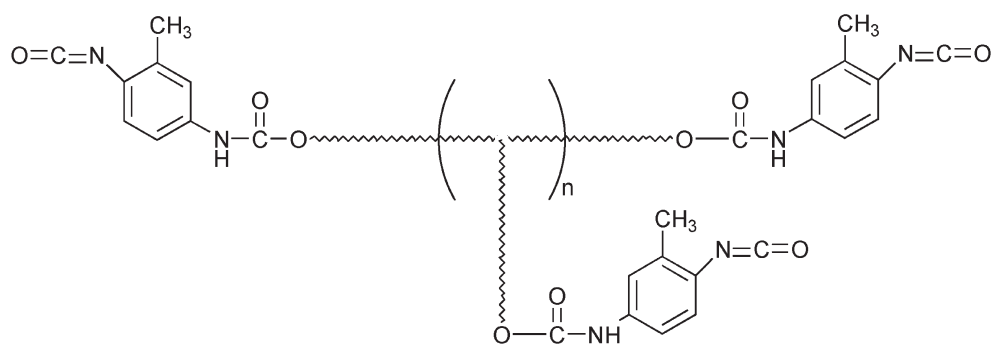

(b)

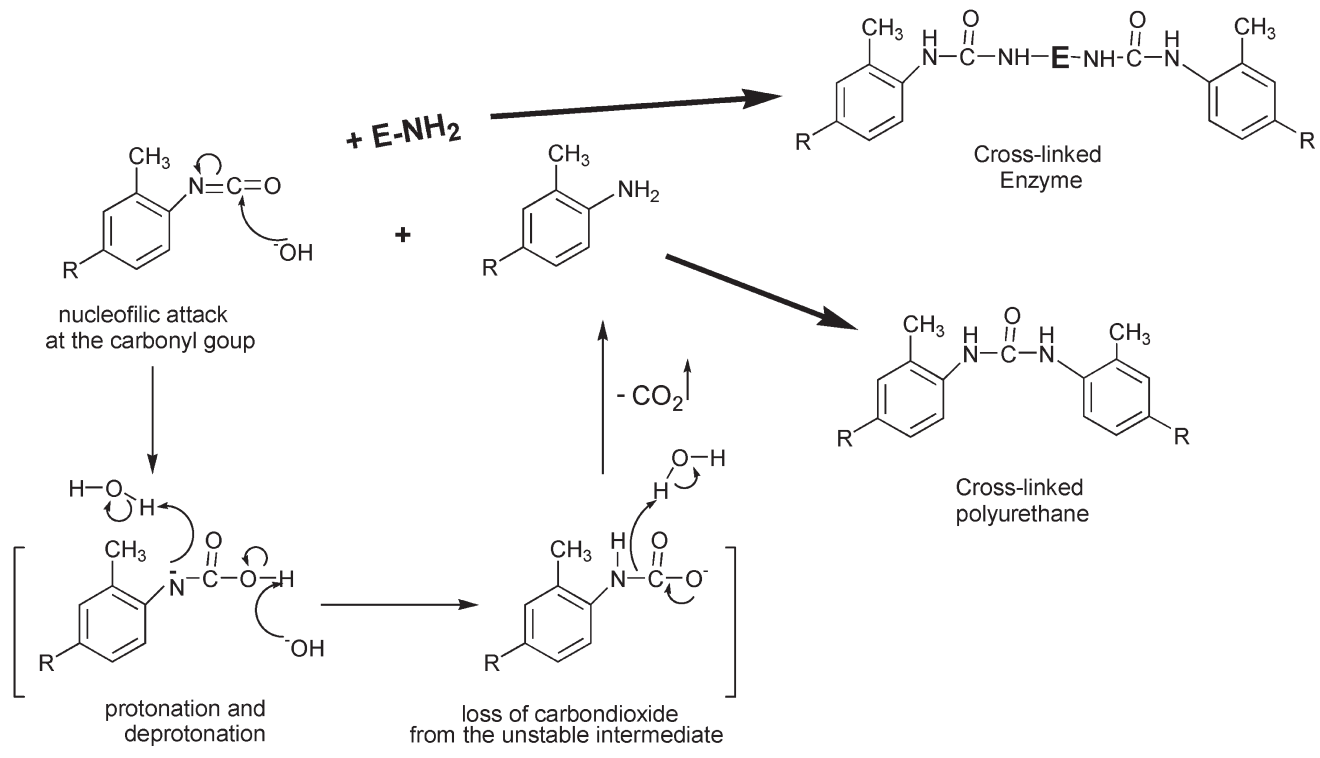

Figure 1. (a) Chemical structure of the HYPOL prepolymer and (b) mechanism of enzyme immobilization by cross-linking within PU foam deduced from isocyanate chemistry.

acetate ( $p$-NPA), and para-nitrophenol ( $p$-NP) were all purchased from Sigma-Aldrich. Acetonitrile $(99.9 \%, v / v)$, sodium hydroxide $(97 \%, \mathrm{w} / \mathrm{w})$, and hydrochloric acid $(35 \%, \mathrm{v} / \mathrm{v})$ were purchased from Merck. PU prepolymer, HYPOL-2060, was provided as a kind gift from Dow Chemical Co., Turkey.

2.2. Immobilization of CA within PU Foam. The immobilization of CA within PU foam was achieved in a similar fashion as described in refs 35 and 36. Briefly, a known amount of CA enzyme in powder form was dissolved in $3 \mathrm{~mL}$ of DI water and poured onto about $3 \mathrm{~g}$ of viscous HYPOL2060 prepolymer in a $50 \mathrm{~mL}$ falcon tube. The two-phase system was mixed vigorously for $30 \mathrm{~s}$ to achieve a homogeneous distribution of the enzyme within the prepolymer. The level of the white polymeric solution started to increase as a result of a $\mathrm{CO}_{2}$ release during the polymerization. The level and, thus, the polymerization settled in 3-5 min. Another $10 \mathrm{~min}$ were allowed for curing. After completion of the enzyme immobilization, a piece of foam was cut from the middle of the whole product and assayed for immobilized CA activity.

This procedure was repeated for the immobilization of various amounts of CA within about $3 \mathrm{~g}$ of HYPOL prepolymer.

2.3. CA Activity Assays. The enzyme activities were measured at $25^{\circ} \mathrm{C}$ by monitoring the changes in the concentration in $p$-NP, which is one of the hydrolysis products of $p$-NPA. For the free $\mathrm{CA}$, the activity assay was performed in a $1 \mathrm{~mL} \mathrm{UV}$ cuvette. The reaction mixture, composed of $0.8 \mathrm{~mL}$ of Tris buffer $(50 \mathrm{mM}$, $\mathrm{pH} 7.5), 0.1 \mathrm{~mL}$ of substrate solution ( $p$-NPA dissolved in acetonitrile), and $0.1 \mathrm{~mL}$ of enzyme solution (the CA in Tris buffer), was mixed in the cuvette by a micropipet. Thus, the final mixture contained $10 \%$ of acetonitrile. The enzyme activity was measured in a Perkin-Elmer UV/vis spectrophotometer at $400 \mathrm{~nm}$ for $3 \mathrm{~min}$. Different concentrations of substrate when the enzyme concentration was constant as well as different concentrations of enzyme when the substrate concentration was constant were tested to determine the free enzyme activity. Blank experiments were also conducted to estimate the selfdissociation of $p$-NPA in each assay solution.

The immobilized CA activity was estimated in a similar fashion as described in refs 35 and 36. Briefly, a piece of CAimmobilized PU foam was washed by squeezing several times in a fresh Tris buffer. In a $30 \mathrm{~mL}$ vial, $1 \mathrm{~mL}$ of substrate solution ( $p$-NPA dissolved in acetonitrile) was mixed with $9 \mathrm{~mL}$ of Tris buffer $(50 \mathrm{mM}, \mathrm{pH} 7.5)$ on a magnetic stirrer. Therefore, the final solution contained $10 \%$ acetonitrile. The reaction started once the initially washed and soaked foam was added into the substrate-containing mixture. In every minute, $1 \mathrm{~mL}$ of sample was withdrawn from the reaction mixture, its absorbance was measured in the UV/vis spectrophotometer at $400 \mathrm{~nm}$ for a short time, and the sample was returned back to the reaction mixture. This procedure was repeated at $1 \mathrm{~min}$ intervals for $25-30 \mathrm{~min}$. At the end of the assay, the foam was washed and dried at $80^{\circ} \mathrm{C}$ under vacuum, after which it was weighed for analysis. Different amounts of foam when the substrate concentration was constant as well as different concentrations of substrate when the same foam was used were tested to determine the immobilized enzyme activity. For the latter, the same foam was washed by squeezing several times in Tris buffer, and the next assay was initiated by adding it to a fresh reaction mixture. 


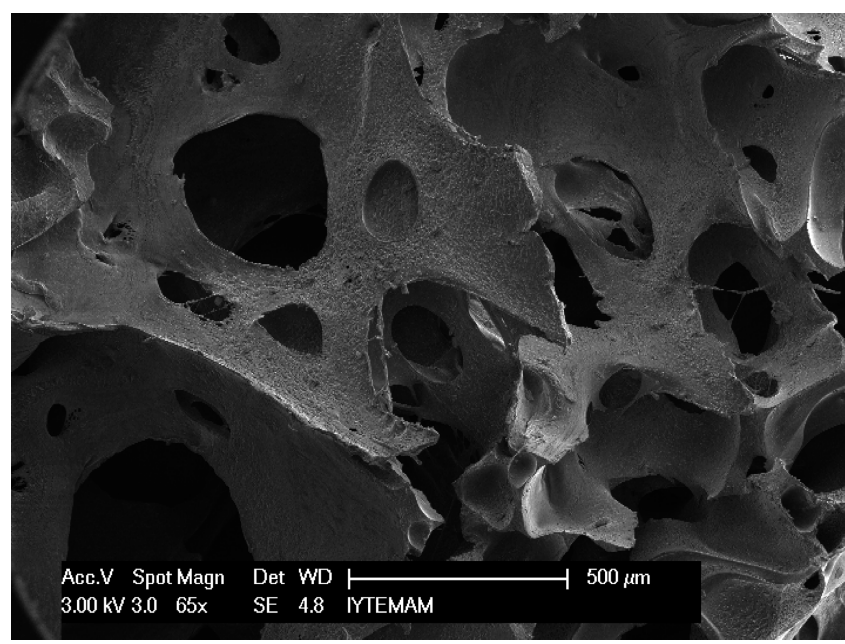

Figure 2. Scanning electron microscopy (SEM) image of the PU foam.

2.4. Reusability of Immobilized CA. A stock solution of $p$-NPA was prepared in acetonitrile. A slice of enzyme-immobilized foam was washed in Tris buffer 5 times and then soaked in fresh Tris buffer. The reaction was initiated by adding the enzyme-immobilized foam into the reaction mixture composed of $1 \mathrm{~mL}$ of stock solution of $p$-NPA and $9 \mathrm{~mL}$ of Tris buffer ( $50 \mathrm{mM}, \mathrm{pH} 7.5)$. The absorbance of the solution was measured at $400 \mathrm{~nm}$ in a UV/vis spectrophotometer at $1 \mathrm{~min}$ intervals for 25-30 min. This procedure was repeated 7 times for the same slice of the enzyme-containing foam sample.

2.5. Stability of Free and Immobilized CA. The stability of the free CA was estimated by the free enzyme activity assay. The known amount of powder CA was dissolved in Tris buffer $(50 \mathrm{mM}, \mathrm{pH} 7.5)$ and stored in the refrigerator at $4{ }^{\circ} \mathrm{C}$. Aliquots from this stock solution were used in the free enzyme activity assay every 3-4 days over 45 days. The stability of the immobilized CA was estimated using the same piece of foam sample stored in Tris buffer $(50 \mathrm{mM}, \mathrm{pH} 7.5)$ at room temperature. The foam sample was washed by squeezing several times in Tris buffer and assayed for the immobilized enzyme activity. At the end of the enzyme activity, the foam was washed again and stored in the Tris buffer until the next activity assay. The activity tests were repeated in every $3-4$ days over 45 days.

\section{Results and Discussion}

3.1. Immobilization of CA within PU Foam. CA was immobilized within PU foam. When isocyanate groups were reacted with water, a gas, carbon dioxide, was released during the immobilization, which resulted in local gas bubbles in the polymeric network. These bubbles created large pores, which made the PU foam a sponge-like material. Those pores were as large as $500 \mu \mathrm{m}$ in size, as shown in Figure 2, which were much larger than about $4 \mathrm{~nm}$ of the size of an enzyme with a molecular weight of $29000 .^{41}$ The larger pores did not affect the enzyme immobilization because the enzyme was immobilized within the polymeric network covalently with multiple attachments rather than by an entrapment or adsorption mechanism. Also, the hydrophilic nature of the PU sponge and large porosity made the PU foam advantageous for enzyme immobilization, where the substrates could easily access the hydrophilic foam and the substrates or the products could easily diffuse in and out of

(41) Huang, S.; Xue, Y.; Sauer-Eriksson, E.; Chirica, L.; Lindskog, S.; Jansson, B.-H. J. Mol. Biol. 1998, 283, 301-310.

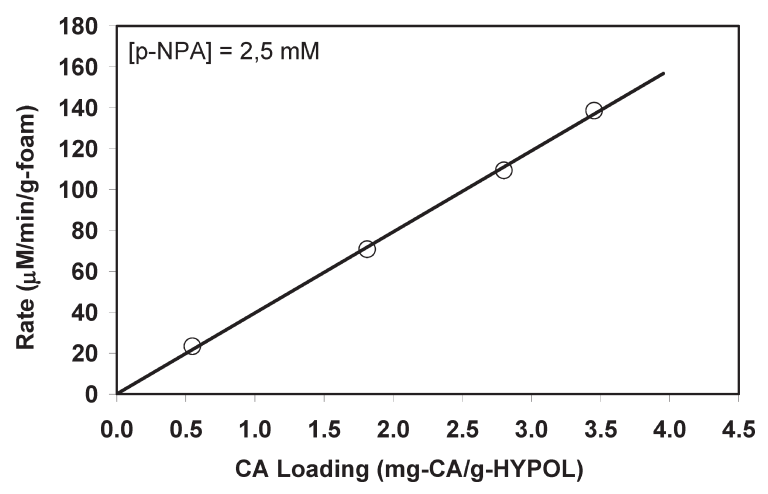

Figure 3. CA loading within PU foam.

the sponge containing the enzyme. ${ }^{36}$ Therefore, the PU foam was found to be a good support material for the CA immobilization.

How much CA could be immobilized within PU foam was tested by mixing different amounts of enzyme with about $3 \mathrm{~g}$ of HYPOL prepolymer. The activities were measured with the immobilized enzyme activity assay on a piece of sample from each loading. The amount of CA enzyme per gram of HYPOL versus the activity as micromolar $p$-NP produced per minute per gram of foam were reported, as shown in Figure 3. As shown in the figure, the enzyme-loading capacity was linear up to $4 \mathrm{mg}$ of $\mathrm{CA} / \mathrm{g}$ of HYPOL. This capacity could be higher when considering the total reactive groups available, such as a $6.2 \times 10^{-7} \mathrm{~mol}$ of lysine $/ \mathrm{mg}$ of CA and $1.5 \times 10^{-3} \mathrm{~mol}$ of isocyanate/g of HYPOL when there are 18 lysines on a CA with a molecular weight of $29000^{25}$ and 3 isocyanate groups per a HYPOL prepolymer with a molecular weight of $2060 .^{38}$ It is hard to tell theoretically how much capacity could be achieved because there are multiple functional groups involved in the cross-linking. The linear trend would indicate the efficiency of immobilization, which would be the same for each immobilization up to $4 \mathrm{mg}$ of CA loading/g of HYPOL.

3.2. Activities of Free and Immobilized CA. The activity of the free CA was estimated using $p$-NPA in the liquid phase instead of gaseous $\mathrm{CO}_{2}$ as the substrate. Although the CA activity was defined as 1 Wilbur-Anderson (W-A) unit, which causes the $\mathrm{pH}$ of a $0.02 \mathrm{M}$ Trizma buffer to drop from 8.3 to $6.3 / \mathrm{min}$ at $0{ }^{\circ} \mathrm{C},{ }^{42}$ this method uses a $\mathrm{CO}_{2}$-saturated solution within $20 \mathrm{mM}$ Trizma buffer and measures the $\mathrm{pH}$ drop from 8.3 to 6.3 at $0{ }^{\circ} \mathrm{C}$. With this respect, Mirjafari et al. investigated the hydration of $\mathrm{CO}_{2}$ by $\mathrm{pH}$ variation and they could capture only $2-4 \mathrm{pH}$ data in $3 \mathrm{~s}$ time intervals. ${ }^{8}$ They estimated the hydration rate in these scattered and limited data points. Similar data were reported by Bond et al., where the pH drop occurred "stepwise" in less than $25 \mathrm{~s} .{ }^{10}$ The enzyme activity estimated from such data could bring large uncertainties. Therefore, the $p$-NPA was selected as the substrate for the free and immobilized CA enzyme activity determination. Also, the selection of $p$-NPA resulted in repeatable experimental results. The self-hydrolysis of the $p$-NPA was investigated in a separate study, and it was found that the rate of self-hydrolysis was concentration- and temperature-dependent, for which it obeyed a first-order kinetic. Here, those data were not reported, but all of the self-hydrolysis rates were subtracted from the raw data of the

(42) Sigma-Aldrich. Carbonic anhydrase from bovine erythrocytes, 2009 (http://www.sigmaaldrich.com/). 


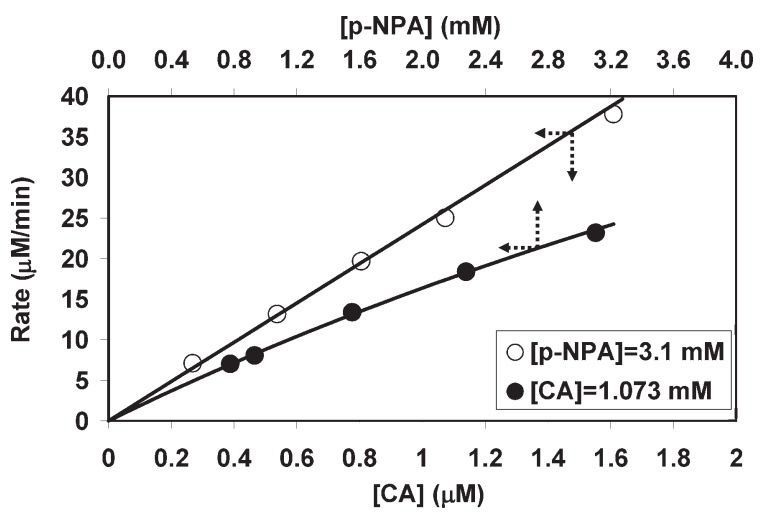

Figure 4. Effect of the substrate concentration as well as the enzyme concentration on the free CA activity.

enzyme-catalyzed hydrolysis rates and reported solely as the CA activity in the given conditions.

The activity of the free CA was estimated at different substrate concentrations while keeping the enzyme concentration constant. The substrate concentration of $p$-NPA could only be used up to $3.1 \mathrm{mM}$ because of the limited solubility of $p$-NPA in the aqueous phase. The activity of the free $\mathrm{CA}$ was also estimated at various enzyme concentrations while keeping the substrate concentration constant. Figure 4 shows the activity of the free CA in Tris buffer $(50 \mathrm{mM}, \mathrm{pH}$ 7.5 ) in the presence of $10 \%$ acetonitrile. The continuous lines shown in the figure are the curve fit of the experimental data to the Michaelis-Menten equation (eq 7) using the estimated kinetic parameters

$$
R=\frac{k_{\mathrm{cat}}[\mathrm{E}][\mathrm{S}]}{K_{\mathrm{m}}+[\mathrm{S}]}
$$

where $R$ is the rate for $p$-NP generation, $R_{\max }\left(=k_{\mathrm{cat}}[\mathrm{E}]\right)$ is the maximum rate when the substrate concentration is infinite, $k_{\text {cat }}$ is the catalytic rate constant or the turnover number, $[\mathrm{E}]$ is the enzyme concentration, $[\mathrm{S}]$ is the substrate concentration, $K_{\mathrm{m}}$ is the substrate concentration when the rate is equal to $R_{\max } / 2$, which also shows the affinity of the enzyme for the substrate, and $k_{\text {cat }} / K_{\mathrm{m}}$ is the kinetic constant when $[\mathrm{S}] \ll K_{\mathrm{m}}$. The kinetic parameters were obtained from the Lineweaver-Burk equation of the double-reciprocal (eq 8).

$$
\frac{1}{R}=\frac{1}{R_{\max }}+\frac{K_{\mathrm{m}}}{R_{\max }} \frac{1}{[\mathrm{~S}]}
$$

The kinetic parameters for the free CA were estimated as $k_{\text {cat }}=2.02 \mathrm{~s}^{-1}, K_{\mathrm{m}}=12.2 \mathrm{mM}$, and $k_{\text {cat }} / K_{\mathrm{m}}=166.4 \mathrm{M}^{-1}$ $\mathrm{s}^{-1}$. Because different types of CAs have different activity with different kinetic constants, it was hard to make an easy comparison between the present data and the literature. For instance, the $K_{\mathrm{m}}$ values for the bovine CA II, ${ }^{26}$ the human CA $\mathrm{II}^{16}$ and the human CA I ${ }^{16}$ were $76.9,30.53$, and $3.02 \mathrm{mM}$, respectively, and the $k_{\mathrm{cat}} / K_{\mathrm{m}}$ values for the same enzymes were 960,2607 , and $753 \mathrm{M}^{-1} \mathrm{~s}^{-1}$, respectively, for $p$-NPA as the substrate. The $k_{\text {cat }} / K_{\mathrm{m}}$ value for the bovine CA was estimated to be $166.4 \mathrm{M}^{-1} \mathrm{~s}^{-1}$, which is in good agreement with the available literature of $153.3 \mathrm{M}^{-1} \mathrm{~s}^{-1} \cdot{ }^{15}$ Also, because the [S] versus rate graph resulted in a linear-like trend at low substrate concentrations, some kinetic date, such as $k_{\mathrm{cat}}$ and $K_{\mathrm{m}}$, were not reported in the literature; instead, $k_{\text {cat }} / K_{\mathrm{m}}$ values

(43) Pocker, Y.; Stone, J. T. Biochemistry 1968, 7 (11), 4139-4145.

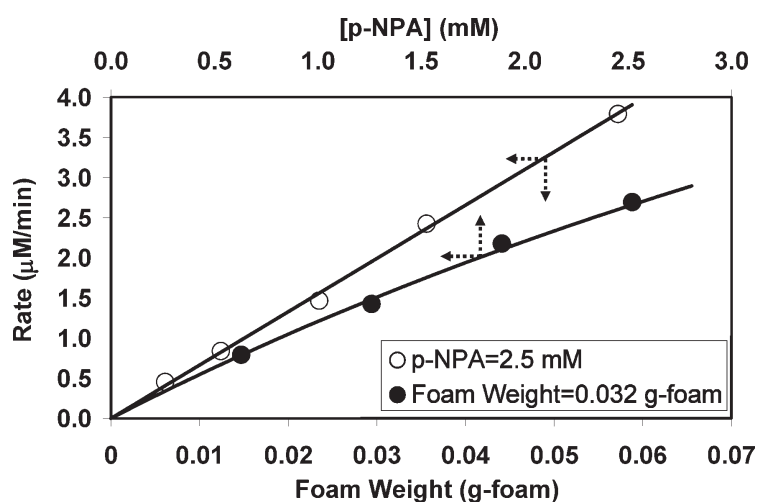

Figure 5. Effect of the substrate concentration as well as the foam weight on the immobilized CA activity.

were reported as the slope. ${ }^{15,16,25,26,28,43}$ This is somehow correct if [S] $\ll K_{\mathrm{m}}$. However, this would be not the case for the bovine CA, where the substrate concentration was up to $3.1 \mathrm{mM}$ and was not much lower than the $K_{\mathrm{m}}$ value of $12.2 \mathrm{mM}$.

The catalytic activity of the immobilized CA was estimated from the liberation of $p$-NP over time by the hydrolysis of $p$-NPA as the substrate. The self-hydrolysis rate for the $p$-NPA was also subtracted from the catalytic hydrolysis rates. Figure 5 shows the experimental data and the curve fit to the Michaelis-Menten model (eq 7). The immobilized enzyme assay was employed for a single foam sample at various substrate concentrations, where the foam contained a fixed amount of CA. Before and after the assay, the piece of foam was washed by squeezing in Tris buffer and used in the assay for the subsequent substrate concentrations up to $2.5 \mathrm{mM}$. In another catalytic assay, the foam samples were cut at various weights and washed in Tris buffer and then each piece of foam sample was assayed at a constant substrate concentration of $2.5 \mathrm{mM}$. As can be seen in the figure, a linear trend was seen between the foam weight and rate, whereas a nonlinear trend was obvious between the substrate concentration and the catalytic rate. The experimental data were evaluated by employing a double-reciprocal Lineweaver-Burk equation (eq 8). From the data, the $K_{\mathrm{m}}$ value for the immobilized CA was found to be $9.6 \mathrm{mM}$ for $p$-NPA in Tris buffer (50 mM, pH 7.5) in the presence of $10 \%$ acetonitrile. Here, the only amount of CA originally mixed with about $3 \mathrm{~g}$ of HYPOL was known during the immobilization. However, how much enzyme was immobilized and how much of it was active in the sponge were not known. In other words, the enzyme and the foam became a composite polymeric material, and the amount of enzyme that was essential for the calculation of $k_{\text {cat }}$ and $k_{\text {cat }} / K_{\mathrm{m}}$ values could not be estimated accurately within the foam. Therefore, the $k_{\text {cat }}$ and $k_{\text {cat }} / K_{\mathrm{m}}$ values could not be reported for the immobilized CA. The $K_{\mathrm{m}}$ value of $9.6 \mathrm{mM}$ for the immobilized CA was slightly lower than the $K_{\mathrm{m}}$ value of $12.2 \mathrm{mM}$ for the free CA. On the other hand, these values were very close when comparing the $K_{\mathrm{m}}$ values of 76.9 and $30.5 \mathrm{mM}$ for the bovine $\mathrm{CA}-\mathrm{II}^{26}$ and human CA-II, ${ }^{16}$ respectively, for the same substrate, $p$-NPA. The difference could be due to the diffusion effect and/or the partition of $p$-NP between the foam and buffer. ${ }^{36}$

3.3. Reusability of Immobilized CA. The most important feature of a covalent attachment of an enzyme is that the immobilized enzyme can hold a constant activity when it is 


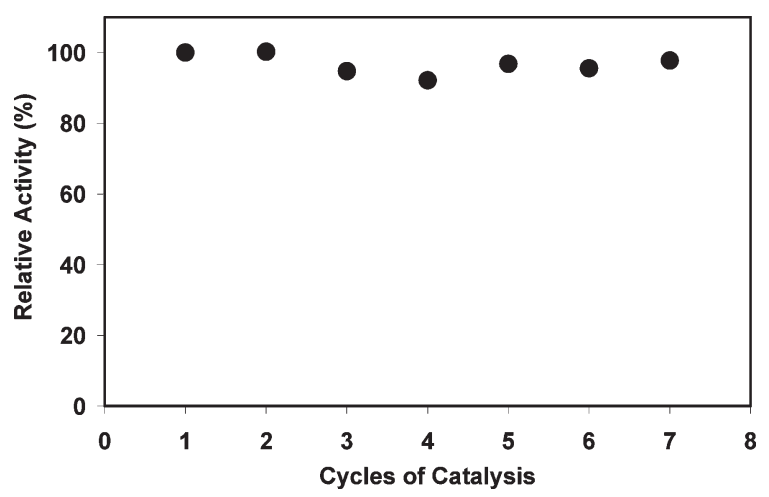

Figure 6. Cycle of usage for CA immobilized within PU foam.

used again and again. High reuse capacity is also crucial for the industrial applications because the production and purification of native enzymes are expensive. Figure 6 shows the reuse capacity of the CA enzyme immobilized within the PU foam for 7 cycles. Between each cycle, the piece of foam was washed by squeezing several times in the Tris buffer and assayed for the immobilized enzyme activity. As shown in the figure, the immobilized enzyme maintained $100 \%$ of its activity during the whole cycles and it was anticipated that the activity would be maintained for subsequent cycles. The strong stability during the cycles of usage indicated that the CA has been covalently attached within PU foam and did not lose its activity by either denaturing or detachment from the polymeric structure.

3.4. Stability of Free and Immobilized CA. The storage stabilities of the free and immobilized CA were estimated simultaneously. The free enzymes can be stored in aqueous solution at low temperatures in a refrigerator to maintain their stability. On the other hand, the immobilized enzymes can be stored as dry or in aqueous solution at either low temperatures in a refrigerator or at laboratory conditions. It is certain that the enzymes are more stable when they were stored at low temperatures in a refrigerator. Here, the free CA was dissolved in Tris buffer ( $50 \mathrm{mM}, \mathrm{pH} 7.5)$ and stored at $4{ }^{\circ} \mathrm{C}$ in the refrigerator. The CA-immobilized PU foam was also placed in the Tris buffer but stored at ambient temperature in the laboratory. The activities of the free and immobilized enzyme were estimated by the free and immobilized enzyme assays using the same substrate concentrations in Tris buffer in the presence of $10 \%$ acetonitrile. Figure 7 shows the relative activities of the free and immobilized CA over time, where the rates were normalized with respect to the rates obtained for the first day. As shown in the figure, there was a dramatic loss in the activity for the free CA. The free CA has lost all of its activity in less than 45 days, although it was stored at $4{ }^{\circ} \mathrm{C}$ in the fridge. The stability of the free CA would have been much shorter if it was stored at room temperature. However, the immobilized CA maintained $100 \%$ of its activity up to 45 days even at room temperature. It can be deduced from the data that the

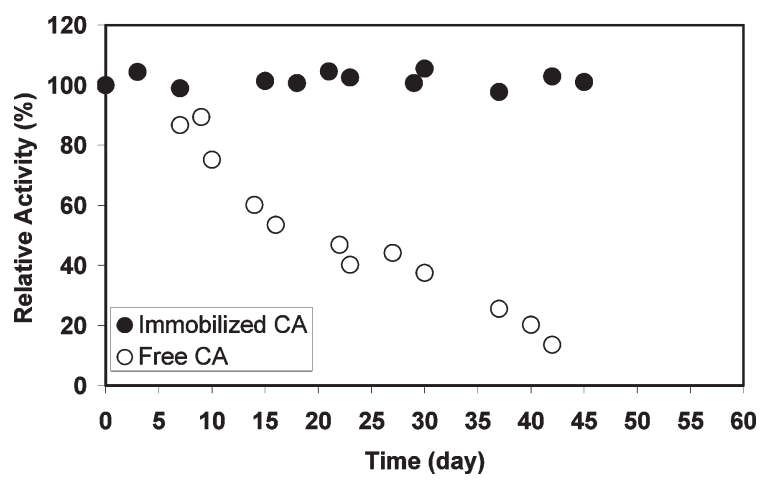

Figure 7. Stability of the free (at $4{ }^{\circ} \mathrm{C}$ ) and immobilized (at room temperature) CA in Tris buffer.

immobilized CA could retain all of its activity for the subsequent duration of time. Improvement of the protein stability is important for enzymes for industrial processes. As shown in the figure, the half-life of the CA was prolonged noticeably by immobilization within the PU foam, which provided a better and convenient biocatalyst for the $\mathrm{CO}_{2}$ sequestration applications.

\section{Conclusion}

The CA can enhance the hydration of $\mathrm{CO}_{2}$ in aqueous solution. However, the free enzyme can lose its activity in solution in short times, and the repeatable usage of the free CA will not be possible when employed in $\mathrm{CO}_{2}$ sequestration purposes. Also, the enzymes are expensive because of their purification costs, and they need to be immobilized for their repeatable usage. There are various methods for enzyme immobilization, such as adsorption on surfaces, entrapment within matrices, or cross-linking within polymeric scaffolds; however, there are some disadvantages, such as detachment from surfaces as in adsorption, mass-transfer limitations as in entrapment, and activity loss as in cross-linking. It was shown that the CA was successfully immobilized within PU foam. The PU foam was found to be a suitable support material for the CA immobilization because the PU foam was a highly porous polymeric material and was highly hydrophilic and the enzyme immobilization was easy and fast. The immobilized CA showed an excellent reuse capacity in aqueous solution, indicating that the enzyme was covalently bound within the polymeric matrix. The immobilized CA was maintained at $100 \%$ of its activity over time, and the excellent stability of the immobilized CA was astonishing. It was concluded that the immobilized CA could be used to accelerate the hydration of $\mathrm{CO}_{2}$ in biomimetic $\mathrm{CO}_{2}$ sequestration in an aqueous solution.

Acknowledgment. The author gratefully acknowledges the support of the Izmir Institute of Technology through project number BAP2006-IYTE-29 and Dow Chemical, Turkey, for donating HYPOL2060. The author also acknowledges Bora Kanbar for helping with part of the activity assays. 